\title{
STUDY ON APPROACHING THE COMPOSITIONAL CRITERION IN GROUP RHYTHMIC GYMNASTICS FOR JUNIOR REPRESENTATIVE TEAMS
}

\author{
Mihaela MANOS ${ }^{1 *}$, Lavinia POPESCU ${ }^{1}$ \\ ${ }^{1}$ National University of Physical Education and Sport, Faculty of Physical Education and Sport, Bucharest, \\ Romania \\ *Corresponding author: manosmihaela@yahoo.com
}

https://doi.org/10.35189/dpeskj.2021.60.3.1

\begin{abstract}
The increased level of sports performance in rhythmic gymnastics due to fiercer and better and better organised competitions is obvious for any critic. National and international sports bodies and public opinion stimulated by media coverage eager for sensational have created an obsession with the prioritisation of values. Obtaining exceptional results, medals, points and titles, with all the deriving moral effects of pride but especially related to material aspects, is of interest to both athletes and the countries represented by sports delegations in official international competitions. Competition analysis provides highly valuable information on the level reached in terms of qualitative and quantitative gains and the impact of regulations on a team's performance at a certain time in relation to the ideal model imposed by the requirements of the FIG Code of Points. Romania's position in the team ranking for the group event in two major competitions generated a number of questions that formed the core of the current study. In this context, we aimed to perform an objective analysis of the way in which coaches approached the compositional criterion in designing the competition routines and identify possibly strategic elements that made the difference in team ranking. The study was conducted on the first 8 junior teams ranked at the 2019 European Rhythmic Gymnastics Championships (Baku) and the 2019 Rhythmic Gymnastics Junior World Championships (Moscow). Video analysis allowed us to identify the vectors that directly or indirectly influenced the mechanisms involved in the creation of compositions for the group event.
\end{abstract}

Keywords: Code of Points, specific requirements, compositional vectors, group event.

\section{Introduction}

The Code of Points has been substantially changed over time in terms of compositional requirements and evaluation criteria for Body Difficulty and Apparatus Difficulty (Toledo \& Antalupa, 2016; Kovalenko \& Boloban, 2017; Hashimoto et al., 2017). These changes have differently influenced the final score, depending on the apparatus. However, Sierra-Palmeiro et al. (2019) believe that the relationship between the number of technical elements and the final score preserves the specificity of the apparatus.

The interest shown by Ávila-Carvalho et al. (2012), Leandro et al. (2017), Hökelmann et al. (2012) or Massidda and Calò (2012) in identifying the effects induced by changes in the content of the Code of Points on some performance indicators in rhythmic gymnastics or in identifying evaluation methods for the Artistic component based on scoring rules reflects the importance given to the in-depth study of these issues, in the context in which the struggle for world supremacy is obviously fiercer.

The synchronisation of a wide range of technical actions with those specific to each apparatus in order to avoid compositional monotony and not to compromise the artistic value 
of difficulties (Ávila-Carvalho et al., 2012; Ávila-Carvalho et al., 2011) is another topic of interest to several specialists in the field.

The congruence between music and movement acquires a major importance in the compositional context (Loo et al., 2019). Musical accompaniment ensures precision, cohesion, spatiotemporal organisation and especially expressiveness to the motor act as a result of the consistency between the means of expression of music and movement.

Technically, the issues related to the floor area are briefly addressed in the Code of Points, although its choreographic importance is crucial, given that space is a factor that influences and models any artistic movement. As an intrinsic component of composition, space becomes an environment where the compositional idea is developed.

\section{Research purpose}

The study aims to identify variants of approaching the compositional criterion and the possible strategic elements, which ultimately make the difference in the team ranking.

\section{Research tasks}

- Establishing the compositional benchmarks that can lead to creating an effective composition in compliance with the requirements of the Code of Points.

- Making a comparative analysis of the scores obtained by the Romanian team and the teams at the top of the ranking.

- Identifying the possibilities of intervention from the perspective of a strategic approach to composition.

\section{Methodology}

The research methods used were: video analysis, mathematical and statistical method (arithmetic mean, standard deviation, coefficient of variation), tabular and graphical methods. Video analysis was performed using the YouTube platform and allowed us to identify the vectors that directly or indirectly influenced the mechanisms involved in the creation of artistic compositions for the group event.

Information technology enabled us to record data and facilitated the identification and subsequent analysis of the compositional elements investigated in our study.

The research was conducted on the 8 top-ranked teams in the group event at two major competitions, namely the 35th European Rhythmic Gymnastics Championships of 2019 held in Baku (Azerbaijan) and the 1st FIG Rhythmic Gymnastics Junior World Championships (FIG, 2019) held in Moscow (Russia), and the Romanian team.

Ethical standards in sport and exercise science research were met, using only publicly available data (Harris \& Atkinson 2009). 
Study design

Scoring system in the 2017-2020 Code of Points

For official FIG competitions, each Jury consists of two groups of judges: D-Panel (Difficulty) and E-Panel (Execution) (Table 1).

Table 1. Functions of the two panels according to the 2017-2020 Code of Points (FIG, 2018)

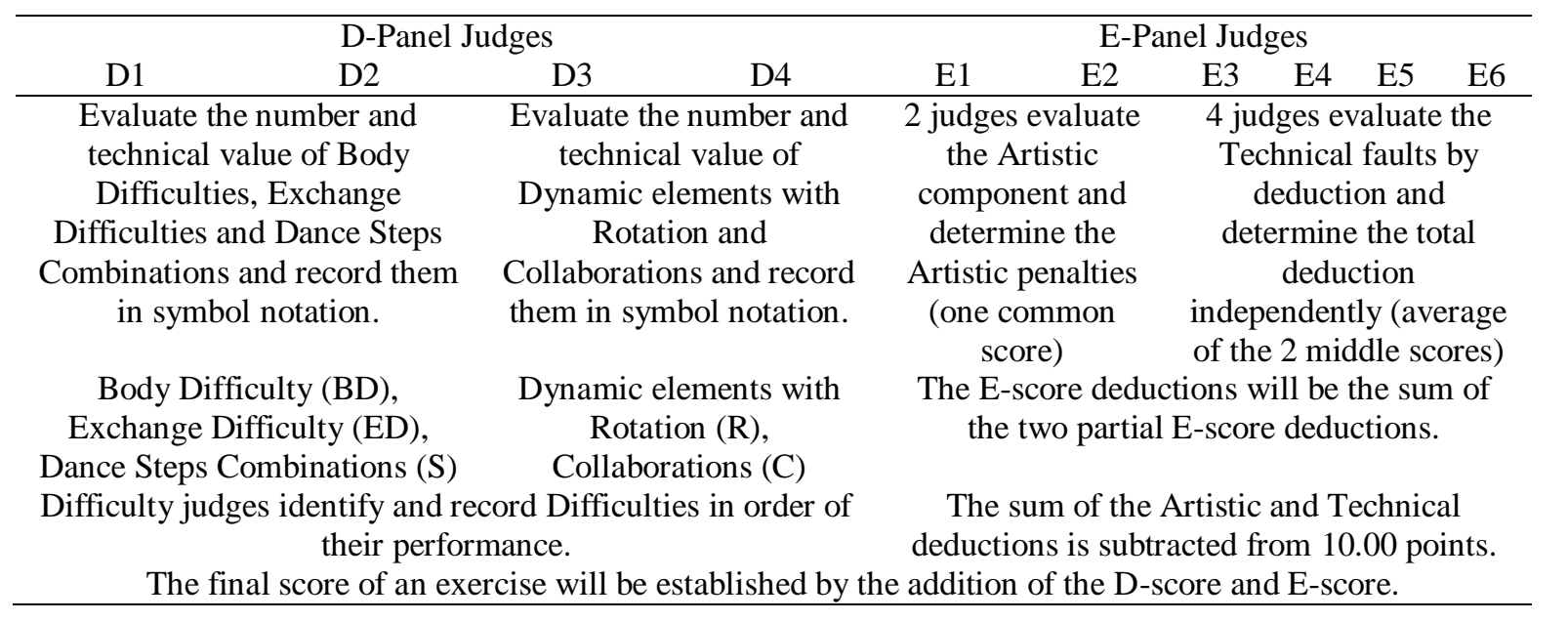

Evaluation criteria for the composition of group exercises in rhythmic gymnastics according to the 2017-2020 FIG Code of Points

To highlight the competitive performance of gymnasts in terms of rules imposed by the FIG Code of Points, a composition must meet the following requirements (Figures 1 and 2):

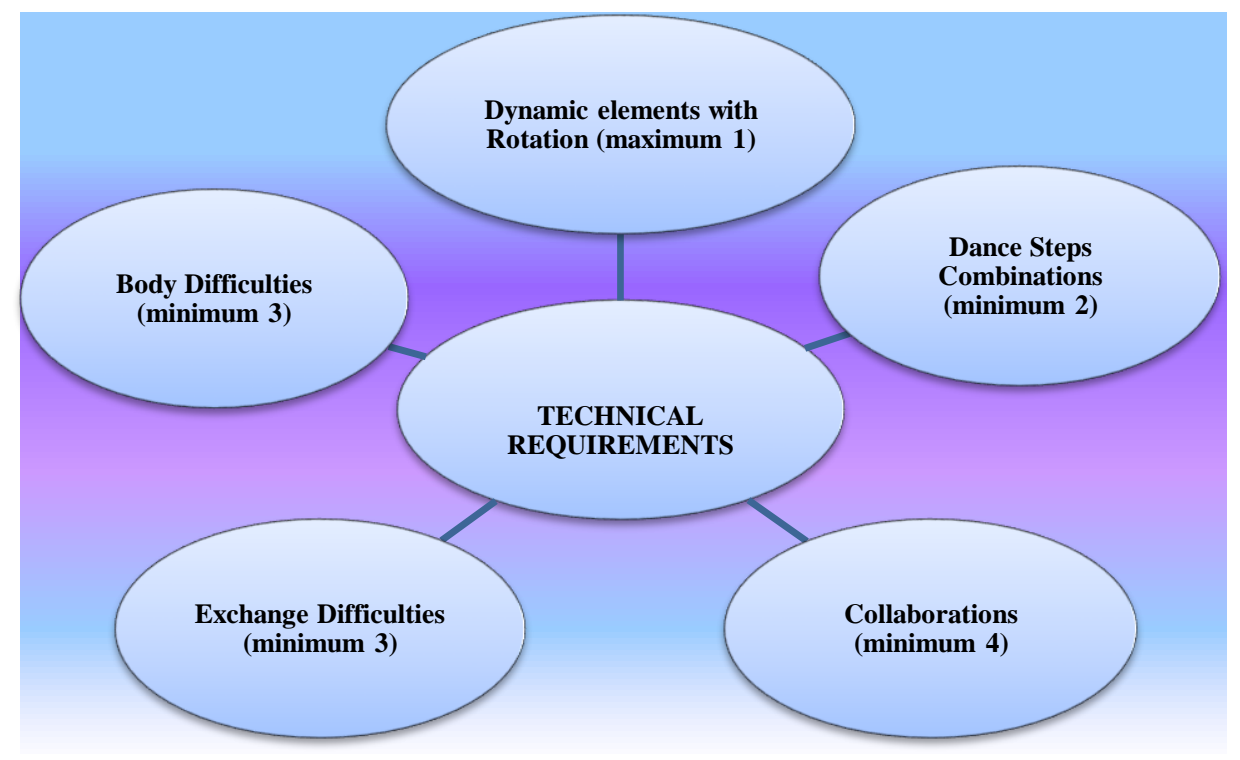

Figure 1. Technical Difficulty criterion for composition 


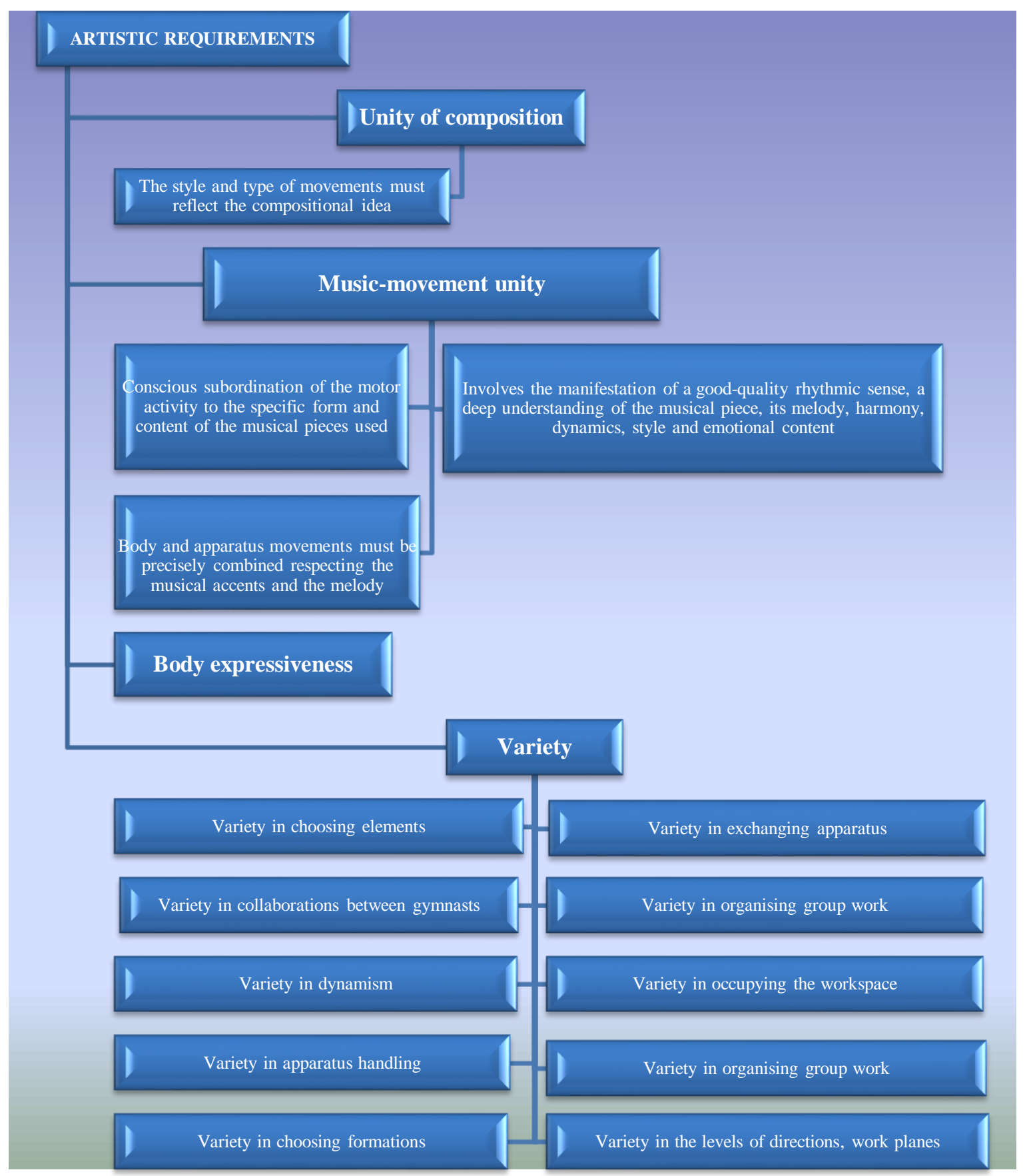

Figure 2. Artistic criterion for composition (Manos \& Popescu, 2020)

The choreographic composition must be indivisible, give meaning to the whole routine and represent a unitary motor discourse consisting of an introduction, a development of the theme and a coherent conclusion; moreover, a wide range of specific actions must be performed using Body Difficulties synchronised with those typical of each apparatus.

The music-movement relationship involves the manifestation of a good-quality rhythmic sense, a deep understanding of the piece of music, its melody, harmony, dynamics, style and emotional content. The coordination of movements with music requires the conscious subordination of the motor activity to the specific form and content of the musical piece used. 
The composition must be an arrangement of defined shapes organised in an orderly, unitary, coherent structure able to attract through the harmony and beauty of the movements.

Movements must be organised in a certain sequence so as to ensure the continuity of the composition. Transitions from one movement to another have to be fluid, with a logical change of planes and/or directions.

The relationship between gymnasts and collaborative work, which is characteristic of the group exercise, derives from the congruent and cooperative participation of each gymnast in the group work. From this point of view, the composition must be designed so as to highlight the idea of collaboration throughout the routine because a group exercise that does not sufficiently express this principle loses its compositional value.

The originality of the choreography represents the qualitative pole of creativity. An original composition is the one that, besides the shapes known as traditional or classical, also includes new elements of choreography with appropriate musical accompaniment.

\section{Operational approach}

- Characteristics of group exercise compositions and scores recorded by the 8 topranked teams and the Romanian team at the 35th European Championships held in Baku (AZE) between 16 and 19 May 2019

The final scores as well as the Technical Difficulty and Execution values were recorded for the 8 top-ranked teams and the Romanian team for the exercise with 5 ribbons (Table 2) and the exercise with 5 hoops (Table 3).

The final score is established by the addition of the Difficulty score and Execution score, from which the penalty is deducted, where applicable. Difficulty is divided into Body Difficulty and Apparatus Difficulty, and Execution is divided into Artistic Execution and Technical Execution.

Table 2. Scores recorded by the 8 top-ranked teams and the Romanian team at the European Championships for the exercise with 5 ribbons

\begin{tabular}{llcccc}
\hline \multicolumn{1}{c}{ Ranking } & \multicolumn{1}{c}{ Country } & Difficulty score & Execution score & Penalties & Final score \\
\hline 1 & Russian Federation & 12.5 & 8.500 & & 21.000 \\
2 & Israel & 11.8 & 8.100 & & 19.900 \\
3 & Belarus & 11.9 & 7.100 & & 19.000 \\
4 & Spain & 10.7 & 7.500 & & 18.200 \\
5 & Italy & 10.2 & 6.100 & & 16.300 \\
6 & Ukraine & 9.4 & 6.150 & & 15.550 \\
7 & Lithuania & 9.9 & 4.950 & -0.600 & 14.850 \\
8 & Switzerland & 9.7 & 5.450 & & 14.550 \\
20 & Romania & 7.6 & 3.200 & & 10.800 \\
\hline
\end{tabular}

For the exercise with 5 ribbons, the score obtained by the Romanian team ranks it last in the qualification competition. 
Table 3. Scores recorded by the 8 top-ranked teams and the Romanian team at the European Championships for the exercise with 5 hoops

\begin{tabular}{|c|c|c|c|c|c|}
\hline Ranking & Country & Difficulty score & Execution score & Penalties & Final score \\
\hline 1 & Russian Federation & 16.1 & 8.350 & & 24.450 \\
\hline 2 & Ukraine & 15.8 & 7.600 & & 23.400 \\
\hline 3 & Belarus & 15.5 & 7.750 & & 23.250 \\
\hline 4 & Italy & 15.5 & 7.400 & & 22.900 \\
\hline 5 & Estonia & 15.5 & 7.050 & & 22.550 \\
\hline 6 & Azerbaijan & 14.8 & 6.700 & & 21.500 \\
\hline 7 & Spain & 12.9 & 7.075 & & 19.975 \\
\hline 8 & Lithuania & 11.9 & 6.200 & -0.300 & 17.800 \\
\hline 17 & Romania & 11.2 & 6.500 & & 17.700 \\
\hline
\end{tabular}

For the exercise with 5 hoops, Romania is only 0.100 points behind the team ranked 8th in the All-Around Finals. For Difficulty, the difference is 0.7 points, and for Execution, 0.300 points, in the conditions in which the team ranked 8th was penalised with -0.300 points.

- Characteristics of group exercise compositions and scores recorded by the 8 topranked teams and the Romanian national team at the 1st FIG Rhythmic Gymnastics Junior World Championships held in Moscow (RUS) between 19 and 21 July 2019

The final scores obtained by the 8 top-ranked teams and the Romanian team for the exercise with 5 ribbons (Table 4) and the exercise with 5 hoops were recorded (Table 5).

Table 4. Scores recorded by the 8 top-ranked teams and the Romanian team at the World Championships for the exercise with 5 ribbons

\begin{tabular}{|c|c|c|c|c|c|c|c|}
\hline \multirow[t]{2}{*}{ Ranking } & \multirow[t]{2}{*}{ Country } & \multicolumn{2}{|c|}{ Difficulty score } & \multicolumn{2}{|c|}{ Execution score } & \multirow[t]{2}{*}{ Penalties } & \multirow{2}{*}{$\begin{array}{l}\text { Final } \\
\text { score }\end{array}$} \\
\hline & & $\begin{array}{c}\text { Body } \\
\text { Difficulty }\end{array}$ & $\begin{array}{l}\text { Apparatus } \\
\text { Difficulty }\end{array}$ & $\begin{array}{l}\text { Artistic Execution } \\
\text { deductions }\end{array}$ & $\begin{array}{c}\text { Technical Execution } \\
\text { deductions }\end{array}$ & & \\
\hline 1 & Russian & 13.400 & & 8.050 & & & 21.450 \\
\hline & Federation & 5.4 & 8.000 & -0.4 & -1.550 & & \\
\hline 2 & Belarus & 12.400 & & 7.150 & & & 19.550 \\
\hline & & 5.1 & 7.3 & -0.8 & -2.050 & & \\
\hline 3 & Israel & 11.600 & & 7.400 & & & 19.000 \\
\hline & & 4.0 & 7.6 & -0.7 & -1.900 & & \\
\hline 4 & Spain & $3.8^{\mathbf{9 . 8 0 0}}$ & 6.0 & $-0.8^{\mathbf{6 . 3 0 0}}$ & -2.900 & -0.05 & 16.050 \\
\hline 5 & Poland & $43^{\mathbf{9 . 7 0 0}}$ & 5.4 & $-12^{\mathbf{5 . 9 5 0}}$ & -2850 & -0.60 & 15.050 \\
\hline 6 & Lithuania & $3.0^{\mathbf{9 . 7 0 0}}$ & 6.7 & $-1.2^{\mathbf{5 . 3 5 0}}$ & -3.450 & & 15.050 \\
\hline 7 & Hungary & $4.3^{\mathbf{1 0 . 1 0 0}}$ & 5.8 & $-1.4^{\mathbf{4 . 6 5 0}}$ & -3.950 & & 14.750 \\
\hline 8 & Italy & $3.5^{10.100}$ & 6.6 & $-1.4^{\mathbf{4 . 7 0 0}}$ & -3.900 & -0.30 & 14.500 \\
\hline 29 & Romania & $2.0{ }^{\mathbf{7 . 5 0 0}}$ & 5.5 & $-1.8^{\mathbf{3 . 0 0 0}}$ & -5.200 & & 10.500 \\
\hline
\end{tabular}

A difference of 4.00 points can be noted between the team ranked 8th and the 29th position obtained by the Romanian team for the exercise with 5 ribbons. 
Table 5. Scores recorded by the 8 top-ranked teams and the Romanian team at the World Championships for the exercise with 5 hoops

\begin{tabular}{|c|c|c|c|c|c|c|c|}
\hline \multirow[t]{2}{*}{ Ranking } & \multirow[t]{2}{*}{ Country } & \multicolumn{2}{|c|}{ Difficulty score } & \multicolumn{2}{|c|}{ Execution score } & \multirow[t]{2}{*}{ Penalties } & \multirow{2}{*}{$\begin{array}{l}\text { Final } \\
\text { score }\end{array}$} \\
\hline & & $\begin{array}{c}\text { Body } \\
\text { Difficulty }\end{array}$ & $\begin{array}{l}\text { Apparatus } \\
\text { Difficulty }\end{array}$ & $\begin{array}{l}\text { Artistic Execution } \\
\text { deductions }\end{array}$ & $\begin{array}{c}\text { Technical Execution } \\
\text { deductions }\end{array}$ & & \\
\hline 1 & Russian & 17.6 & & 8.650 & & & 26.250 \\
\hline & Federation & 5.8 & 11.8 & -0.4 & -0.950 & & \\
\hline 2 & Italy & 17.20 & & 7.900 & & & 25.100 \\
\hline & & 5.4 & 11.8 & -0.6 & -1.500 & & \\
\hline 3 & Belarus & $5.4^{\mathbf{1 6 . 8 0}}$ & 11.4 & $-0.6^{\mathbf{7 . 8 5 0}}$ & -1.550 & & 24.650 \\
\hline 4 & Israel & 16.00 & & 6.300 & & & 22.300 \\
\hline 5 & Spain & $\begin{array}{ll}5.1 & \\
& \mathbf{1 4 . 5 0}\end{array}$ & 10.9 & $\stackrel{-1.1}{\mathbf{7 . 4 5 0}}$ & -2.600 & & 21.950 \\
\hline 6 & Estonia & $\begin{array}{ll}5.2 & \\
& \mathbf{1 4 . 7 0}\end{array}$ & 9.3 & $\begin{array}{l}-0.7 \\
\quad 6.750\end{array}$ & -1.850 & & 21.450 \\
\hline & & 4.5 & 10.2 & -1.2 & -2.050 & & \\
\hline 7 & Azerbaijan & $4.4^{\mathbf{1 3 . 4 0}}$ & 9.0 & $-1.0^{\mathbf{6 . 5 5 0}}$ & -2.450 & & 19.950 \\
\hline 8 & Hungary & $4.9^{13.10}$ & 8.2 & $-1.1^{\mathbf{6 . 1 5 0}}$ & -2.750 & -0.30 & 18.950 \\
\hline 17 & Romania & $5.0^{\mathbf{1 2 . 2 0}}$ & 7.2 & $-2.0^{\mathbf{5 . 5 0 0}}$ & -2.500 & & 17.700 \\
\hline
\end{tabular}

The difference between the team ranked 8th and the 17th position obtained by the Romanian team for the exercise with 5 hoops is 1.25 points.

\section{Results and Discussion}

Table 6. Results obtained by the representative teams of Russia and Romania for the exercise with 5 ribbons at the European Championships, Baku (AZE)

\begin{tabular}{llcccc}
\hline Ranking & Country & Difficulty score & Execution score & Penalties & Final score \\
\hline 1 & Russia & 12.5 & 8.5 & & 21 \\
20 & Romania & 7.6 & 3.2 & 10.8 \\
\hline
\end{tabular}

Table 7. Statistical analysis of the results obtained for the exercise with 5 ribbons

\begin{tabular}{lccc}
\hline Statistical indicators & Difficulty & Execution & Final score \\
\hline AVERAGE & 10.05 & 5.85 & 15.9 \\
STDEV & 3.4648232 & 3.7476659 & 7.21248917 \\
CV & 34.475853 & 64.062666 & 45.3615671 \\
\hline
\end{tabular}

Comparing the scores of the Russian and Romanian teams in the group event with 5 ribbons, the arithmetic mean for the Difficulty score is 10.05, for the Execution score, 5.85, and for the final score, 15.90. The standard deviation is 3.46 for the Difficulty score, 3.74 for the Execution score and 7.21 for the final score. The coefficient of variation for all the above scores exceeds the threshold of $20 \%$, which means that the group is inhomogeneous. (Table 6, Table 7 and Figure 3) 


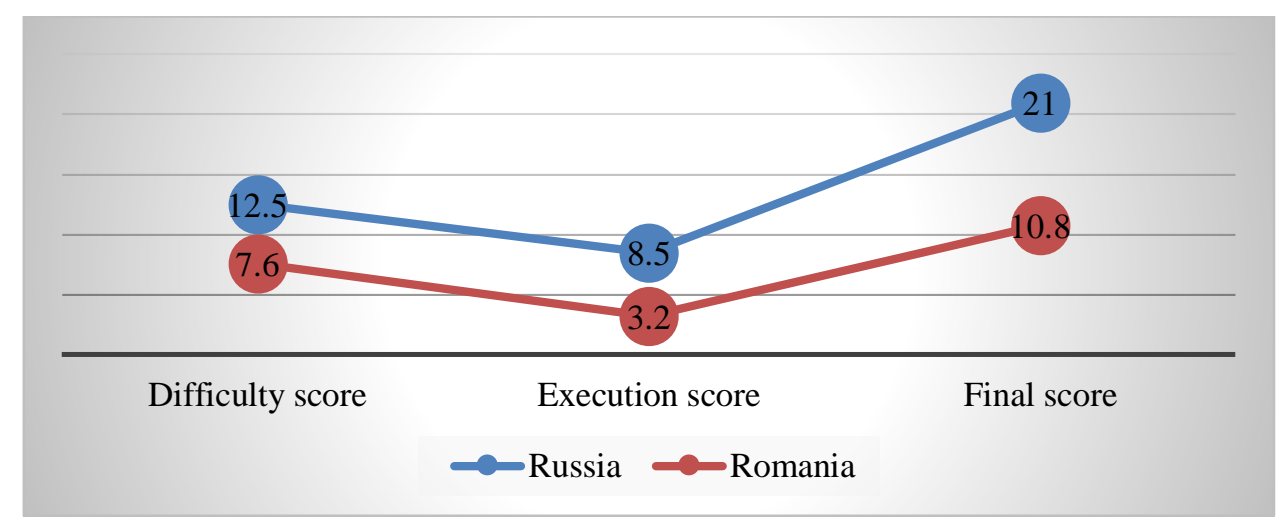

Figure 3. Comparison between the scores obtained by the representative teams of Russia and Romania for the exercise with 5 ribbons

Table 8. Results obtained by the representative teams of Russia and Romania for the exercise with 5 hoops at the European Championships, Baku (AZE)

\begin{tabular}{llcccc}
\hline Ranking & Country & Difficulty score & Execution score & Penalties & Final score \\
\hline 1 & Russia & 16.1 & 8.35 & & 24.45 \\
17 & Romania & 11.2 & 6.5 & 17.8 \\
\hline
\end{tabular}

Table 9. Statistical analysis of the results obtained for the exercise with 5 hoops

\begin{tabular}{lccc}
\hline Statistical indicators & Difficulty & Execution & Final score \\
\hline AVERAGE & 13.65 & 7.425 & 21.125 \\
STDEV & 3.4648232 & 1.3081475 & 4.70226009 \\
CV & 25.38332 & 17.618149 & 22.2592194 \\
\hline
\end{tabular}

Comparing the scores of the Russian and Romanian teams in the group event with 5 hoops, the coefficient of variation for the Difficulty criterion is $25.38 \%$, for the Execution criterion, $17.61 \%$, and for the final score, $22.25 \%$ (Table 8, Table 9 and Figure 4).

In terms of Difficulty and final score criteria, the group is inhomogeneous, while from the perspective of the Execution criterion, the group is relatively homogeneous.

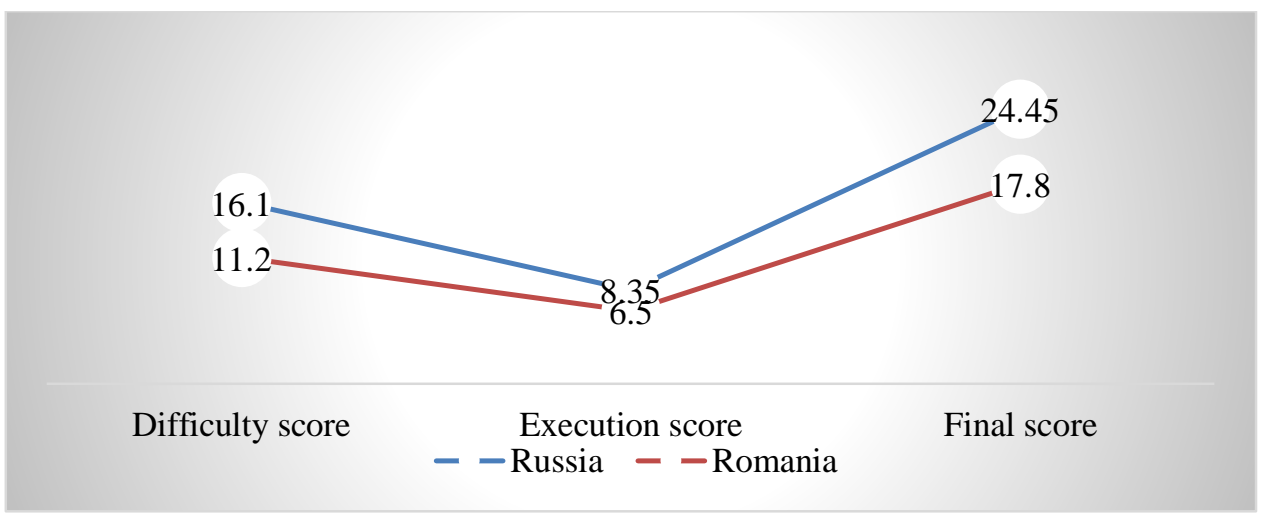

Figure 4. Comparison between the scores obtained by the representative teams of Russia and Romania for the exercise with 5 hoops 
Table 10. Results obtained by the representative teams of Lithuania and Romania for the exercise with 5 ribbons at the European Championships, Baku (AZE)

\begin{tabular}{llcccc}
\hline Ranking & Country & Difficulty score & Execution score & Penalties & Final score \\
\hline 7 & Lithuania & 9.9 & 4.95 & -0.6 & 14.85 \\
20 & Romania & 7.6 & 3.2 & & 10.8 \\
\hline
\end{tabular}

Table 11. Statistical analysis of the results obtained for the exercise with 5 ribbons

\begin{tabular}{lccc}
\hline \multicolumn{1}{c}{ Statistical indicators } & Difficulty & Execution & Final score \\
\hline AVERAGE & 8.75 & 4.075 & 12.825 \\
STDEV & 1.6263456 & 1.2374369 & 2.86378246 \\
CV & 18.586807 & 30.366549 & 22.3296878 \\
\hline
\end{tabular}

The coefficient of variation for the final score exceeds the threshold of $20 \%$, which means that the group is inhomogeneous, but in terms of the Difficulty score, it is relatively homogeneous (Table 10, Table 11 and Figure 5).

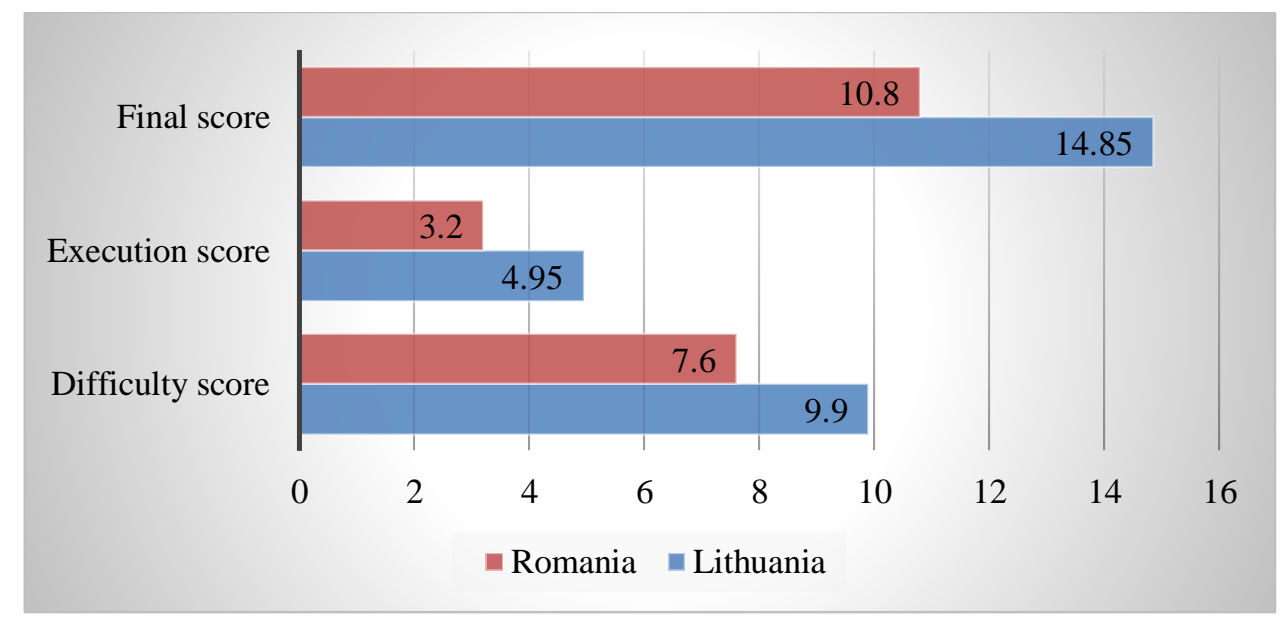

Figure 5. Comparison between the scores obtained by the representative teams of Lithuania and Romania for the exercise with 5 ribbons

Table 12. Results obtained by the representative teams of Lithuania and Romania for the exercise with 5 hoops at the European Championships, Baku (AZE)

\begin{tabular}{lccccc}
\hline Ranking & Country & Difficulty score & Execution score & Penalties & Final score \\
\hline 8 & Lithuania & 11.9 & 6.2 & -0.3 & 17.8 \\
17 & Romania & 11.2 & 6.5 & & 17.7 \\
\hline
\end{tabular}

Table 13. Statistical analysis of the results obtained for the exercise with 5 hoops

\begin{tabular}{lccc}
\hline \multicolumn{1}{c}{ Statistical indicators } & Difficulty & Execution & Final score \\
\hline AVERAGE & 11.55 & 6.35 & 17.75 \\
STDEV & 0.4949747 & 0.212132 & 0.07071068 \\
CV & 4.2854956 & 3.340662 & 0.39837002 \\
\hline
\end{tabular}


Comparing the scores of the Lithuanian and Romanian teams in the group event with 5 hoops, it is noted that the threshold of $10 \%$ is not reached, which shows the homogeneity of the group (Table 12, Table 13 and Figure 6).

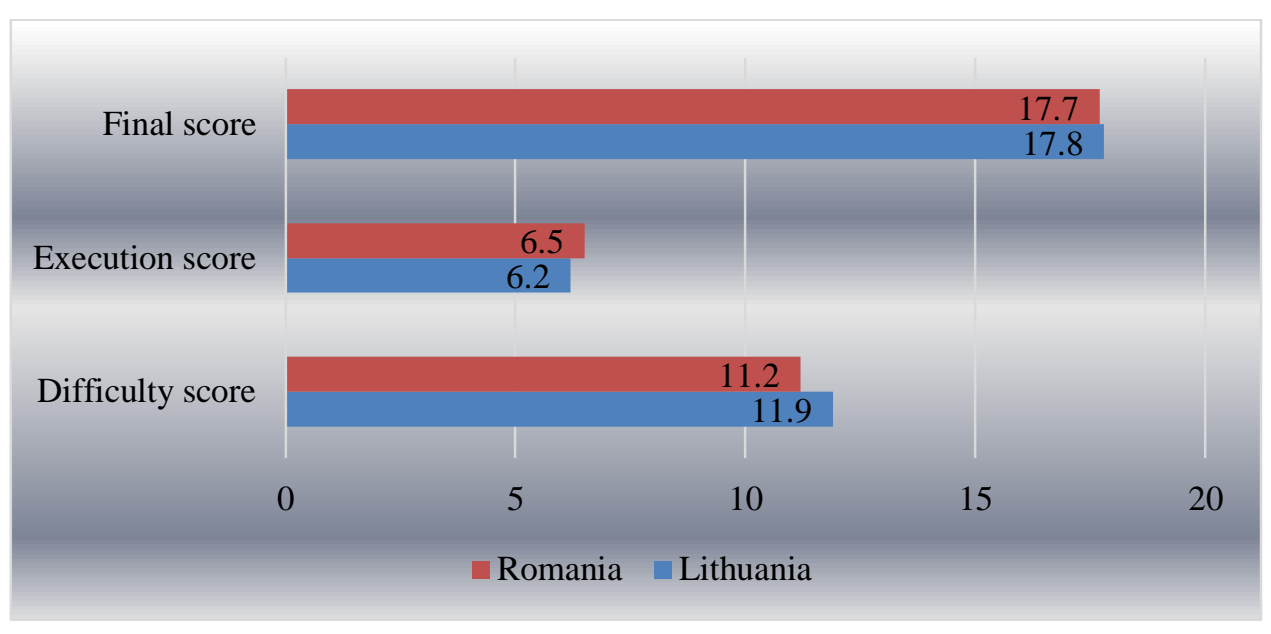

Figure 6. Comparison between the scores obtained by the representative teams of Lithuania and Romania for the exercise with 5 hoops

Table 14. Results obtained by the representative teams of Russia and Romania for the exercise with 5 ribbons at the World Championships, Moscow (RUS)

\begin{tabular}{|c|c|c|c|c|c|c|c|c|c|}
\hline Ranking & Country & $\begin{array}{c}\text { Body } \\
\text { Difficulty }\end{array}$ & $\begin{array}{l}\text { Apparatus } \\
\text { Difficulty }\end{array}$ & $\begin{array}{c}\text { Difficulty } \\
\text { score }\end{array}$ & $\begin{array}{c}\text { Artistic } \\
\text { Execution } \\
\text { deductions } \\
\end{array}$ & $\begin{array}{r}\text { Technical } \\
\text { Execution } \\
\text { deductions }\end{array}$ & $\begin{array}{c}\text { Execution } \\
\text { score }\end{array}$ & Penalties & $\begin{array}{l}\text { Final } \\
\text { score }\end{array}$ \\
\hline 1 & Russia & 5.4 & 8 & 13.4 & -0.4 & -1.55 & 8.05 & & 21.45 \\
\hline 29 & Romania & 2 & 5.5 & 7.5 & -1.8 & -5.2 & 3 & & 10.5 \\
\hline
\end{tabular}

Table 15. Statistical analysis of the results obtained for the exercise with 5 ribbons

\begin{tabular}{lccccccc}
\hline $\begin{array}{l}\text { Statistical } \\
\text { indicators }\end{array}$ & $\begin{array}{c}\text { Body } \\
\text { Difficulty }\end{array}$ & $\begin{array}{c}\text { Apparatus } \\
\text { Difficulty }\end{array}$ & $\begin{array}{c}\text { Difficulty } \\
\text { score }\end{array}$ & $\begin{array}{c}\text { Artistic } \\
\text { Execution } \\
\text { deductions }\end{array}$ & $\begin{array}{c}\text { Technical } \\
\text { Execution } \\
\text { deductions }\end{array}$ & $\begin{array}{c}\text { Execution } \\
\text { score }\end{array}$ & Final score \\
\hline AVERAGE & 3.7 & 6.75 & 10.45 & -1.1 & -3.375 & 5.525 & 15.975 \\
STDEV & 2.4041631 & 1.767767 & 4.17193 & 0.9899495 & 2.5809398 & 3.5708892 & 7.7428193 \\
CV & 64.97738 & 26.18914 & 39.922775 & -89.99541 & -76.47229 & 64.63148 & 48.468352 \\
\hline
\end{tabular}

The coefficient of variation is quite high for all evaluation criteria, the group being inhomogeneous because the threshold of $20 \%$ is exceeded (Table 14, Table 15 and Figure 7). 


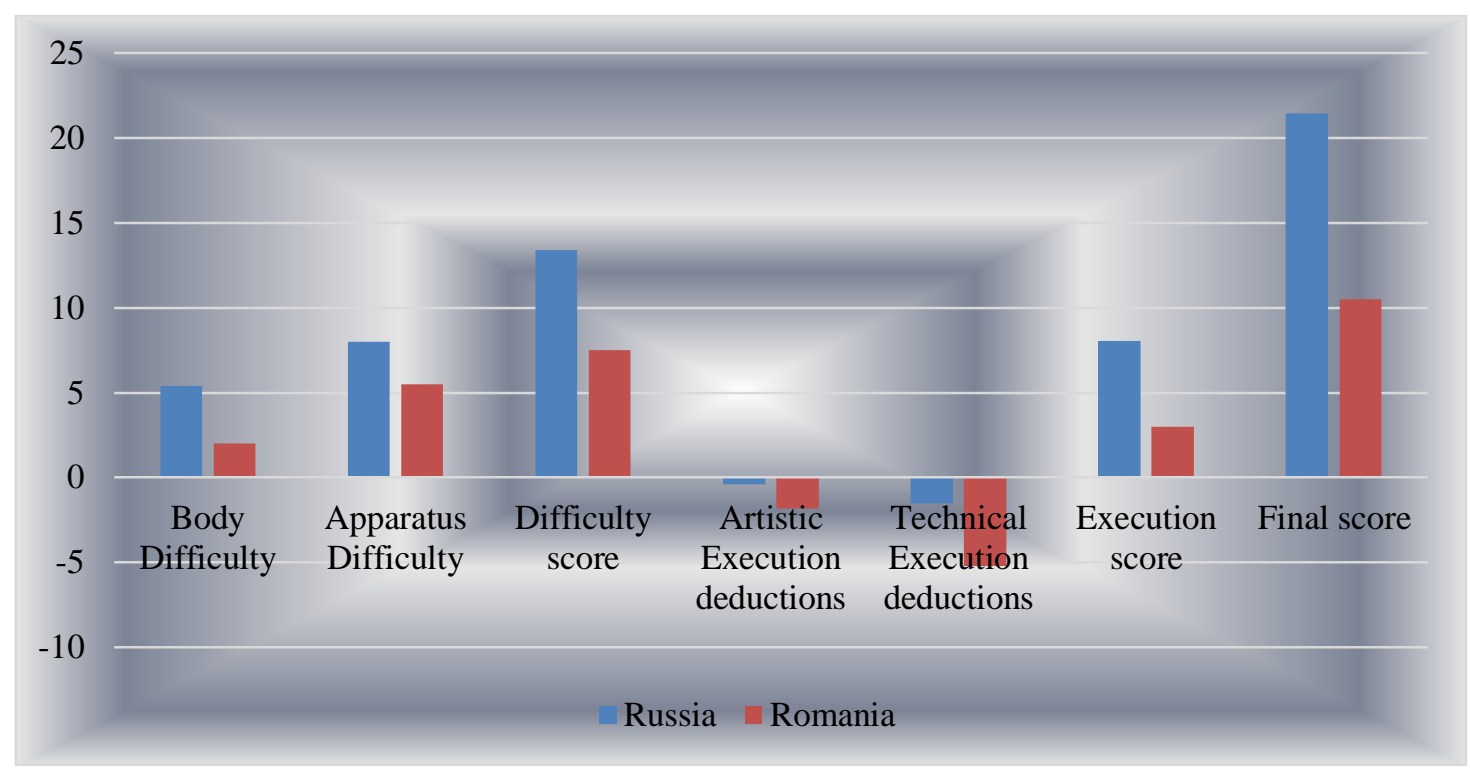

Figure 7. Comparison between the scores obtained by the representative teams of Russia and Romania for the exercise with 5 ribbons

Table 16. Results obtained by the representative teams of Russia and Romania for the exercise with 5 hoops at the World Championships, Moscow (RUS)

\begin{tabular}{|c|c|c|c|c|c|c|c|c|c|}
\hline Ranking & Country & $\begin{array}{c}\text { Body } \\
\text { Difficulty }\end{array}$ & $\begin{array}{l}\text { Apparatus } \\
\text { Difficulty }\end{array}$ & $\begin{array}{l}\text { Difficulty } \\
\text { score }\end{array}$ & $\begin{array}{c}\text { Artistic } \\
\text { Execution } \\
\text { deductions }\end{array}$ & $\begin{array}{l}\text { Technical } \\
\text { Execution } \\
\text { deductions }\end{array}$ & $\begin{array}{l}\text { Execution } \\
\text { score }\end{array}$ & Penalties & $\begin{array}{l}\text { Final } \\
\text { score }\end{array}$ \\
\hline 1 & Russia & 5.8 & 11.8 & 17.6 & -0.4 & -0.95 & 8.65 & & 26.25 \\
\hline 17 & Romania & 5 & 7.2 & 12.2 & -0.2 & -2.5 & 5.5 & & 17.7 \\
\hline
\end{tabular}

Table 17. Statistical analysis of the results obtained for the exercise with 5 hoops

\begin{tabular}{lccccccc}
\hline $\begin{array}{l}\text { Statistical } \\
\text { indicators }\end{array}$ & $\begin{array}{c}\text { Body } \\
\text { Difficulty }\end{array}$ & $\begin{array}{c}\text { Apparatus } \\
\text { Difficulty }\end{array}$ & $\begin{array}{c}\text { Difficulty } \\
\text { score }\end{array}$ & $\begin{array}{c}\text { Artistic } \\
\text { Execution } \\
\text { deductions }\end{array}$ & $\begin{array}{c}\text { Technical } \\
\text { Execution } \\
\text { deductions }\end{array}$ & $\begin{array}{c}\text { Execution } \\
\text { score }\end{array}$ & Final score \\
\hline AVERAGE & 5.4 & 9.5 & 14.9 & -0.3 & -1.725 & 7.075 & 21.975 \\
STDEV & 0.5656854 & 3.2526912 & 3.8183766 & 0.1414214 & 1.0960155 & 2.2273864 & 6.045763 \\
CV & 10.475656 & 34.238855 & 25.626689 & -47.14045 & -63.53713 & 31.482493 & 27.512004 \\
\hline
\end{tabular}

Comparing the scores of the Russian and Romanian teams in the group event with 5 hoops, the coefficient of variation for the Apparatus Difficulty, Execution and final scores exceeds the threshold of $20 \%$, which means that the group is inhomogeneous. A $10.4 \%$ coefficient of variation is obtained for Body Difficulty, which indicates that the homogeneity is relative and the Body Difficulty level has been evaluated as being close to that of the Russian team (Table 16, Table 17 and Figure 8). 


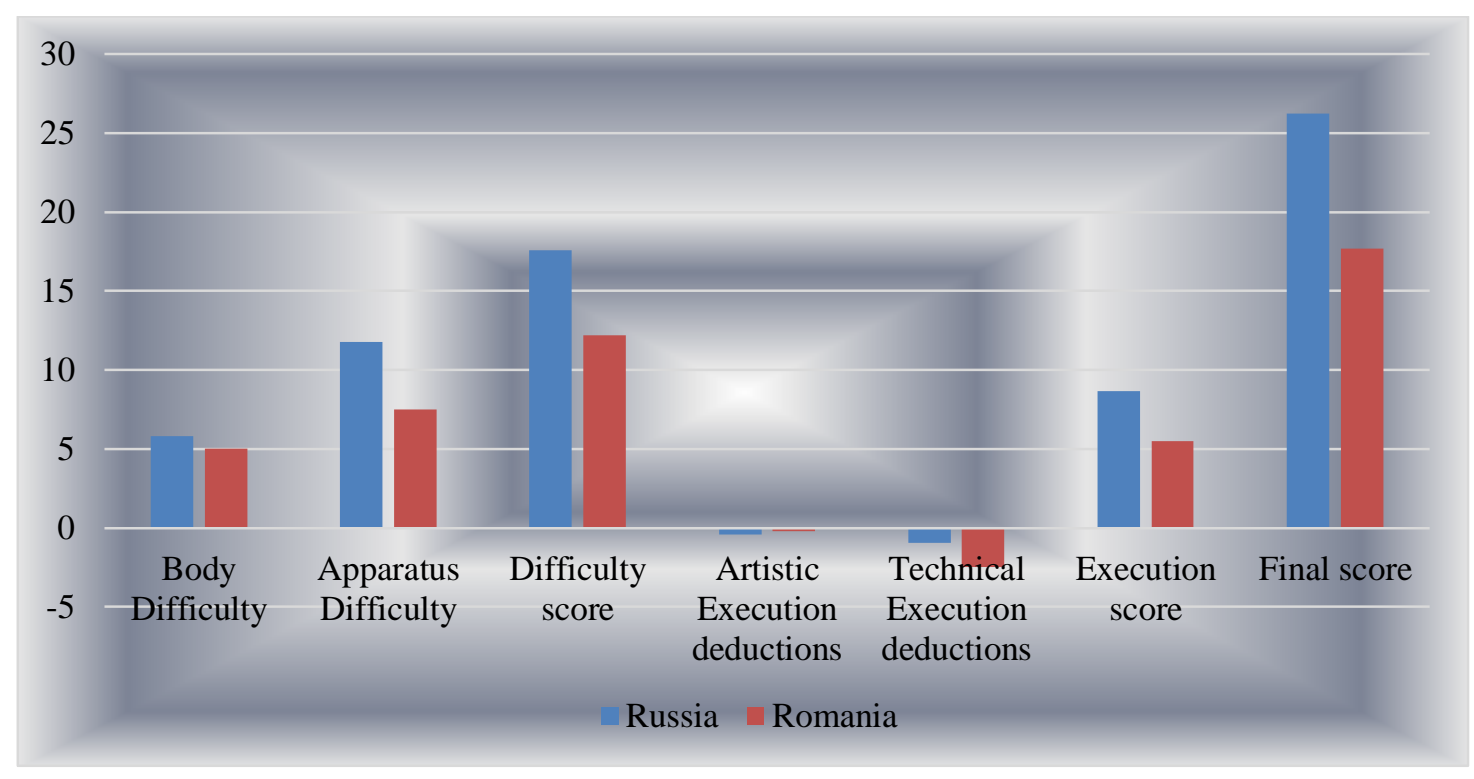

Figure 8. Comparison between the scores obtained by the representative teams of Russia and Romania for the exercise with 5 hoops

Table 18. Results obtained by the representative teams of Lithuania and Romania for the exercise with 5 ribbons at the World Championships, Moscow (RUS)

\begin{tabular}{|c|c|c|c|c|c|c|c|c|c|}
\hline Ranking & Country & $\begin{array}{c}\text { Body } \\
\text { Difficulty }\end{array}$ & $\begin{array}{l}\text { Apparatus } \\
\text { Difficulty }\end{array}$ & $\begin{array}{l}\text { Difficulty } \\
\text { score }\end{array}$ & $\begin{array}{c}\text { Artistic } \\
\text { Execution } \\
\text { deductions }\end{array}$ & $\begin{array}{l}\text { Technical } \\
\text { Execution } \\
\text { deductions }\end{array}$ & $\begin{array}{l}\text { Execution } \\
\text { score }\end{array}$ & Penalties & $\begin{array}{l}\text { Final } \\
\text { score }\end{array}$ \\
\hline 6 & Lithuania & 3 & 6.7 & 9.7 & -1.2 & -3.45 & 5.35 & & 15.05 \\
\hline 29 & Romania & 2 & 5.5 & 7.5 & -1.8 & -5.2 & 3 & & 10.5 \\
\hline
\end{tabular}

Table 19. Statistical analysis of the results obtained for the exercise with 5 ribbons

\begin{tabular}{lccccccc}
\hline $\begin{array}{l}\text { Statistical } \\
\text { indicators }\end{array}$ & $\begin{array}{c}\text { Body } \\
\text { Difficulty }\end{array}$ & $\begin{array}{c}\text { Apparatus } \\
\text { Difficulty }\end{array}$ & $\begin{array}{c}\text { Difficulty } \\
\text { score }\end{array}$ & $\begin{array}{c}\text { Artistic } \\
\text { Execution } \\
\text { deductions }\end{array}$ & $\begin{array}{c}\text { Technical } \\
\text { Execution } \\
\text { deductions }\end{array}$ & $\begin{array}{c}\text { Execution } \\
\text { score }\end{array}$ & $\begin{array}{c}\text { Final } \\
\text { score }\end{array}$ \\
\hline AVERAGE & 2.5 & 6.1 & 8.6 & -1.5 & -4.325 & 4.175 & 12.775 \\
STDEV & 0.7071068 & 0.8485281 & 1.5556349 & 0.4242641 & 1.2374369 & 1.6617009 & 3.2173359 \\
CV & 28.284271 & 13.910297 & 18.088778 & -28.28427 & -28.61126 & 39.80122 & 25.184625 \\
\hline
\end{tabular}

Comparing the scores of the Lithuanian and Romanian teams in the group event with 5 ribbons, the arithmetic mean for the Difficulty score is 8.6, for the Execution score, 4.1, and for the final score, 12.7. The standard deviation is 1.55 for the Difficulty score, 1.66 for the Execution score and 3.21 for the final score. The coefficient of variation obtained for the Difficulty criterion is $18.08 \%$, for the Execution criterion, $39.80 \%$, and for the final score, $25.18 \%$. If only the final score is taken into account, the group is inhomogeneous. However, it is noticed that the coefficient of variation is $13.91 \%$ for Apparatus Difficulty, which means a relatively homogeneous group. For Body Difficulty, the threshold of $28.28 \%$ indicates inhomogeneity, although the total score obtained for Difficulty shows that the group has a relative homogeneity. (Table 18, Table 19 and Figure 9) 


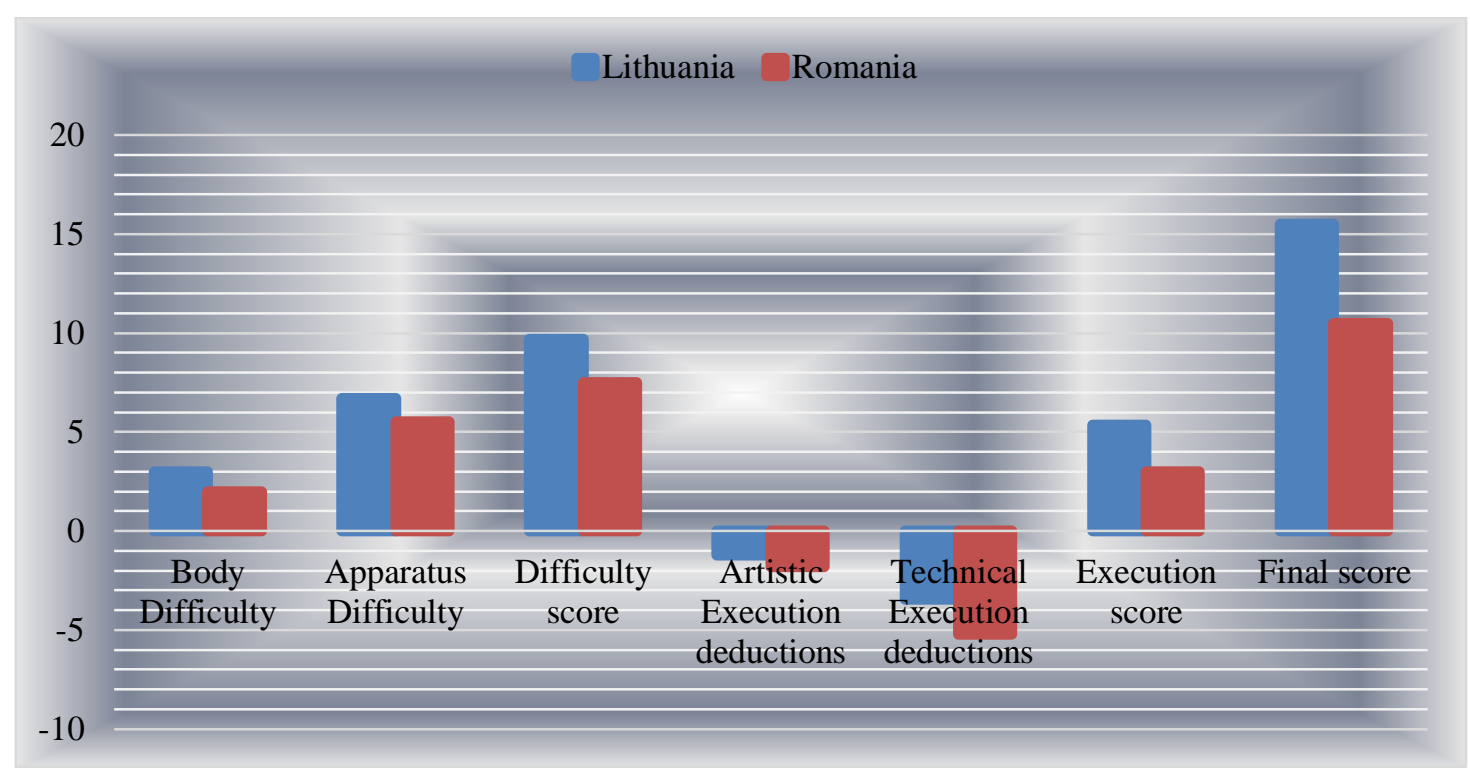

Figure 9. Comparison between the scores obtained by the representative teams of Lithuania and Romania for the exercise with 5 ribbons

Lithuania did not rank among the first 8 teams in the All-Around group event finals with 5 hoops.

Comparative analysis of the exercise content in compositional terms for the 8 top-ranked teams and the Romanian team

The analysis is focused on two compositional aspects, Collaborations and Formations, which are found in the content of the ribbon and hoop group exercises (Table 20).

Table 20. Current European and global levels in organising the competition exercise content for the group event

\begin{tabular}{|c|c|c|c|c|}
\hline Country & Group/Apparatus & Collaborations & Formations & Travelling Formations \\
\hline \multirow[t]{2}{*}{ RUSSIA } & 5 ribbons & 18 & 11 & 10 \\
\hline & 5 hoops & 22 & 12 & 9 \\
\hline \multirow[t]{2}{*}{ ITALY } & 5 ribbons & 17 & 10 & 13 \\
\hline & 5 hoops & 20 & 11 & 10 \\
\hline \multirow[t]{2}{*}{ BELARUS } & 5 ribbons & 16 & 10 & 12 \\
\hline & 5 hoops & 19 & 11 & 14 \\
\hline \multirow[t]{2}{*}{ ISRAEL } & 5 ribbons & 18 & 8 & 11 \\
\hline & 5 hoops & 20 & 8 & 8 \\
\hline \multirow[t]{2}{*}{ SPAIN } & 5 ribbons & 15 & 10 & 9 \\
\hline & 5 hoops & 20 & 11 & 8 \\
\hline \multirow[t]{2}{*}{ ESTONIA } & 5 ribbons & 15 & & \\
\hline & 5 hoops & 20 & 9 & 8 \\
\hline \multirow{2}{*}{ AZERBAIJAN } & 5 ribbons & & & \\
\hline & 5 hoops & 20 & 9 & 7 \\
\hline \multirow[t]{2}{*}{ HUNGARY } & 5 ribbons & 15 & 8 & 10 \\
\hline & 5 hoops & 18 & 11 & 10 \\
\hline \multirow[t]{2}{*}{ ROMANIA } & 5 ribbons & 14 & 9 & 11 \\
\hline & 5 hoops & 20 & 12 & 10 \\
\hline
\end{tabular}




\begin{tabular}{|c|c|c|c|c|}
\hline \multirow[t]{2}{*}{ LITHUANIA } & 5 ribbons & 17 & 12 & 8 \\
\hline & 5 hoops & 20 & 12 & 8 \\
\hline \multirow[t]{2}{*}{ POLAND } & 5 ribbons & 16 & 9 & 10 \\
\hline & 5 hoops & & & \\
\hline \multirow[t]{2}{*}{ UKRAINE } & 5 ribbons & 14 & 11 & 12 \\
\hline & 5 hoops & 19 & 9 & 8 \\
\hline \multirow[t]{2}{*}{ SWEDEN } & 5 ribbons & 15 & 12 & 10 \\
\hline & 5 hoops & & & \\
\hline
\end{tabular}

Compositionally, in terms of Collaborations and Formations, the routines performed by the Romanian team in the two competitions complied with the regulatory requirements. However, this is not enough to rank in the top eight. In both competitive events, the number of values by Difficulty evaluation sub-criterion is lower, which affects the final score.

\section{Conclusion}

The comparative analysis of the scores obtained by the Romanian team in the two competitions, namely the 2019 European Rhythmic Gymnastics Championships and the 2019 Rhythmic Gymnastics Junior World Championships, highlighted the compositional vectors on which to act in order to reduce the gap between our team and top teams.

To reach a better position in the ranking, a greater importance should be given to synchronisation in the group work, with a focus on both the body and the apparatus.

The execution of Body Difficulties should be safe and based on a correct technique, which would facilitate the use of other high-value Difficulties.

From a compositional point of view, the issues related to Collaborations, variety in apparatus handling actions and Dynamic elements with Rotation should be highlighted more.

\section{References}

Ávila-Carvalho, L., da Luz Palomero, M., \& Levre, E. (2011). Estudio del valor artístico de los ejercicios de conjunto de Gimnasia Rítmica de la Copa del Mundo de Portimão 2007 y 2008 [Study of the artistic value of group exercises at the Portimão Rhythmic Gymnastics World Cup in 2007 and 2008]. Apunts. Educación Física y Deporte, 103, 68-75.

Ávila-Carvalho, L., Klentrou, P., da Luz Palomero, M., Klentrouand, P., \& Lebre, E. (2012). Analysis of the technical content of elite rhythmic gymnastics group routines. Open Sports Science Journal, 5, 146-153. https://doi.org/10.2174/1875399x01205010146

European Rhythmic Gymnastics Championships. (2019). Results book: Results by apparatus. https://www.europeangymnastics.com/event/2019-european-championships-rhythmicgymnastics/overview

FIG. (2018). 2017-2020 Code of Points: Rhythmic Gymnastics. Lausanne. https://www.gymnastics.sport/publicdir/rules/files/en_RG\%20CoP\%2020172020\%20with\%20Errata\%20Dec.\%2017.pdf

FIG. (2019). 1st FIG Rhythmic Gymnastics Junior World Championships, Moscow. https://gym.longinestiming.com/2019/Rhythmic-15968/en-us/default

Harris, D. J., \& Atkinson, G. (2009). Ethical standards in sport and exercise science research. International Journal of Sports Medicine, 30(10), 701-702. https://doi.org/10.1055/s-0029-1237378 
Hashimoto, M., Kida, N., \& Nomura, T. (2017). Characteristics of Women's Rhythmic Gymnastics from the perspective of "Body Difficulty" and performance time. Advances in Physical Education, 7(3), 260-273. https://doi.org/10.4236/ape.2017.73021

Hökelmann, A., Breitkreutz, T., \& Livioty, G. (2012). Changes in performance structure during group competitions in rhythmic gymnastics. In M. Peters \& P. O. Donoghue (Eds.), Book of Abstracts of the World Congress of the Performance Analysis of Sport, IX. University of Worcester.

Kovalenko, Y. O., \& Boloban, V. N. (2017). Analysis of Olympic Games (Rio de Janeiro, 2016) participants' individual competition compositions in calisthenics. Pedagogics, Psychology, Medical-Biological Problems of Physical Training and Sports, 21(3). https://doi.org/10.15561/18189172.2017.0303

Leandro, C., Ávila-Carvalho, L., Sierra-Palmeiro, E., \& Bobo-Arce, M. (2017). Judging in rhythmic gymnastics at different levels of performance. Journal of Human Kinetics, 60(1), 159-165. https://doi.org/10.1515/hukin-2017-0099

Loo, F. C., Loo, F. Y., \& Chua, Y. P. (2019). Congruence in music and movement enhances the perception of sports routine quality. Música Hodie, 19: e5819. https://doi.org/10.5216/mh.v19.58191

Manos, M., \& Popescu, L. (2020). The impact induced by the 2009-2012 FIG Code of Points on the artistic compositions in rhythmic gymnastics group event. Procedia - Social and Behavioural Sciences, 117, 300-306. https://doi.org/10.1016/j.sbspro.2014.02.217

Massidda, M., \& Calò, M. C. (2012). Performance scores and standings during the 43rd Artistic Gymnastics World Championships 2011. Journal of Sports Sciences, 30(13), 1415-1420. https://doi.org/10.1080/02640414.2012.710759

Sierra-Palmeiro, E., Bobo-Arce, M., Pérez-Ferreirós, A., \& Fernanández-Villarino, M. (2019). Longitudinal study of individual exercises in elite rhythmic gymnastics. Frontiers in Psychology. https://doi.org/10.3389/fpsyg.2019.01496

Toledo, E., \& Antalupa, K. (2016). The appreciation of artistic aspects of the Code of Points in rhythmic gymnastics: An analysis of the last three decades. Revista Brasileira de Educação Física e Esporte, 30(1). https://doi.org/10.1590/1807-55092016000100119 